\title{
Perencanaan/Pengendalian dan Pengembangan Potensi Sumber Daya Air Kabupaten Pasuruan
}

\author{
Sukobar \\ Staf Pengajar Program Studi Diploma Teknik Sipil FTSP ITS
}

\begin{abstract}
ABSTRAK
Air merupkan salah satu kebutuhan pokok bagi kehidupan sehari - hari. Oleh karena itu Pengolahan Sumber Daya Air perlu dilakukan agar potensi sumber daya air yang ada dapat dipergunakan dengan baik (tidak mengakibatkan efek negatife pada lingkungan yang akan menggangu kelangsungan ketersediaan sumber daya air). Pengolahan sumber daya air tergantung pada potensi sumber daya air yang ada dan kebutuhan air yang akan digunakan. Potensi sumber daya air terdiri dari air permukaan dan air bawah tanah, sedangkan kebutuhan air terdiri dari kebutuhan air bersih, kebutuhan air industri dan kebutuhan air pertanian. Dalam studi pengelolaan potensi sumber daya air di Kabupaten Pasuruan dilakukan penggabungan pengelolaan data identifikasi potensi sumber daya air dengan proyeksi kebutuhan air sampai dengan tahun 2012. Maka diperoleh identifikasi potensi sumber daya air mempunyai kapasitas air permukaan 4.933.876.748 $\mathrm{m}^{3}$ / tahun, kapasitas air bawah tanah $629.946 .438 \mathrm{~m}^{3} /$ tahun. Sedangkan untuk proyeksi kebutuhan air diperoleh Kebutuhan air Domestik $=137.870 .812 \mathrm{~m}^{3} /$ Tahun atau 4.371,85 liter/ detik, Kebutuhan Air Industri $=9.159 .675 \mathrm{~m}^{3}$ / Tahun atau 290,45 liter/ detik, Kebutuhan Air Pertanian $=2.955 .009 .359 \mathrm{~m}^{3} /$ Tahun atau 93.702,73 liter/ detik. J adi Total kebutuhan air di Kabupaten Pasuruan sampai tahun 2012 adalah 3.102.039.846 $\mathrm{m}^{3} /$ Tahun atau 98.365, 04 liter/ detik. Sehingga dapat disimpulkan bahwa kebutuhan air bersih dan air industri di Kabupaten Pasuruan dapat dipenuhi oleh Air Bawah Tanah. Kebutuhan air bersih, air industri dan air pertaniaan di Kabupaten Pasuruan dapat dipenuhi oleh Air Bawah Tanah dan Air Permukaan. Di musim kemarau sumber daya air di Kabupaten Pasuruan tidak dapat memenuhi kebutuhan air yang ada di Kabupaten Pasuruan sehingga perlu dibangun sarana penampung air/ reservoar (waduk/ dam/ embung).
\end{abstract}

\section{PENDAHULUAN}

Air merupakan salah satu kebutuhan pokok bagi kehidupan manusia, oleh sebab itu diperlukan ketersediaan air yang memenuhi persyaratan mutu (kualitas) sesuai dengan persyaratan, dalam jumlah (kuantitas) yang cukup dan tersedia setiap waktu (Kontinu). Air juga merupakan salah satu sumber daya alam yang mempunyai nilai ekonomis yang tinggi bila dikelola dengan baik dan optimal.

Pengelolaan dan pemanfaatan sumber daya air akan meningkat seiring dengan laju pertambahan penduduk, peningkatan taraf hidup dan pertumbuhan perekonomian daerah. Seiring dengan kondisi tersebut akan terjadi perubahan tata guna lahan (tata ruang) daerah, yang tentunya akan mengakibatkan keseimbangan air di daerah tersebut akan berubah.

Kebutuhan air pada kehidupan sehari - hari digunakan untuk kebutuhan air bersih untuk aktifitas penduduk seperti rumah tangga (domestik), kebutuhan air industri untuk perindustrian, kebutuhan air pertanian.

Dalam upaya pengelolaan sumber daya air yang berwawasan lingkungan dan berkelanjutan mutlak dilakukan, dalam artian setiap kegiatan pengelolaan sumber daya air harus disesuaikan dengan potensi yang ada, sehingga tidak mengakibatkan efek negatif pada lingkungan yang akan mengganggu kelangsungan ketersediaan sumber daya air di masa datang.

Pada Studi ini akan mengelola potensi sumber daya air (Air Permukaan dan Air Bawah Tanah)di Kabupaten Pasuruan terhadap jumlah kebutuhan air (Water Demand) menurut kualitas air dan peruntukannya. 


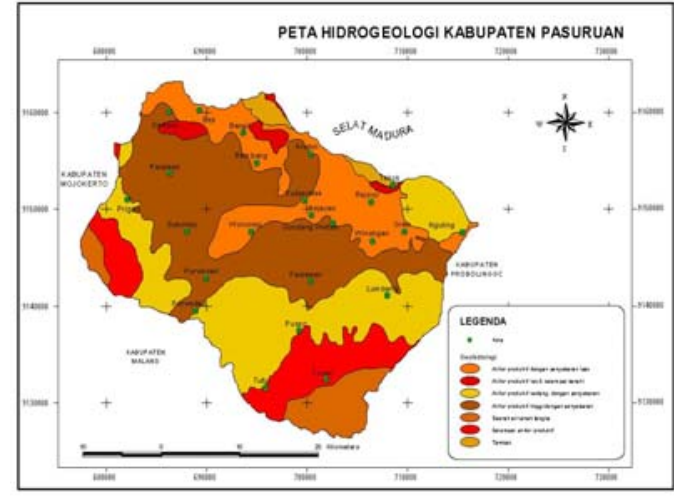

Gambar 1. Peta Hidrogeologi Kab. Pasuruan

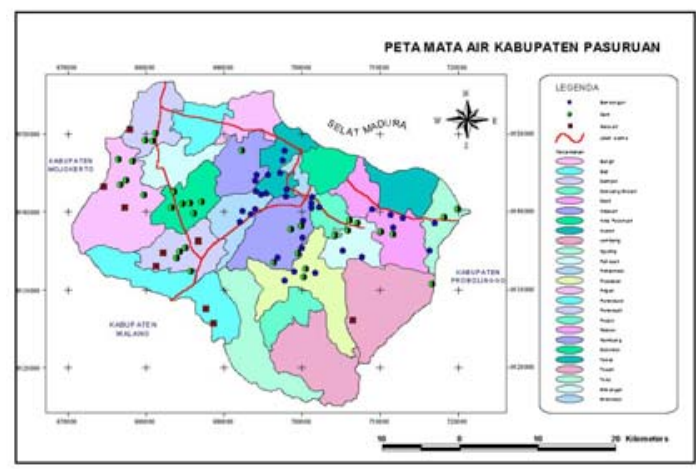

Gambar 2. Peta Mata Air Kab. Pasuruan

\section{TINJ AUAN PUSTAKA}

Pada Studi ini mendefinisikan bahwa Pengelolaan Potensi Sumber Daya Air di Kabupaten Pasuruan tergantung pada Potensi Sumber Daya Air yang ada dan Proyeksi Kebutuhan Air (Water Demand).

\subsection{Potensi Sumber Daya Air}

Ditinjau dari lokasi pengaliran air, sumber daya air di Kabupaten Pasuruan dibagi menj adi dua kelompok yaitu :

a. Air Permukaan, yaitu air yang media pengalirannya berada di permukaan tanah. seperti : sungai, danau.

Kapasitas air pada masing - masing Daerah Tangkapan Air di Kabupaten Pasuruan dipengaruhi oleh parameter - parameter :

- Curah hujan.

- Luas daerah tangkapan air.

- Kondisi permukaan air.

- Kondisi geologi.

- Evaporasi.

\section{Dengan Perumusan}

Kapasitas Air Permukaan $=\mathrm{C} \times \mathrm{I}$ x A

$\mathrm{C}=$ Koefisien

I = Intensitas Hujan $(\mathrm{mm} / \mathrm{jam})$

$A=$ Luas Catchment Area $\left(\mathrm{m}^{2}\right)$

b. Air Bawah Tanah, yaitu air yang media pengalirannya berada di bawah tanah. Seperti : air sumur, mata air.

Kapasitas air bawah tanah di pengaruhi oleh parameter - parameter :

- Jumlah air hujan ( Presipitasi ).

- Lapisan permukaan ( Run Off ) / Air Permukaan.

- Penguapan ( Evaporasi ).

\subsection{Proyeksi Kebutuhan Air (Water Demand)}

Proyeksi Kebutuhan Air (Water Demand) di Kabupaten Pasuruan menurut kualitas air dan peruntukannya dapat didikelompokan menjadi 3 ( Tiga ) kelompok yaitu :

a. Kebutuhan Air Bersih untuk aktifitas penduduk seperti rumah tangga (domestik).

Kebutuhan air bersih untuk masyarakat meliputi kebutuhan untuk rumah tangga, sarana pendidikan dan sarana ibadah.

b. Kebutuhan Air Industri untuk kegiatan industri.

Kebutuhan air industri per kecamatan di Kabupaten Pasuruan untuk 10 tahun mendatang dipengaruhi oleh :

- Jumlah industri.

- J enis industri.

c. Kebutuhan Air Untuk Pertanian

Kebutuhan air untuk pertanian tergantung pada :

- Luas area pertanian.

- J enis tanaman.

- Jenis tanah ( Perkolasi ).

- Evaporasi.

Dengan Perumusan

$\mathrm{n}=\mathrm{p} \times \mathrm{q} \times\left[\mathrm{Z}_{\mathrm{a} / 2} / \mathrm{E}\right]^{2}$

\subsection{Peramalan}

\section{a. Metode Regresi Linier}

Persamaan umum regresi linier sederhana adalah :

$Y=a+b X$

dimana :

$\mathrm{Y}=$ peubah tak bebas, yaitu hasil yang ingin diketahui 
$X=$ peubah bebas, yaitu parameter yang diketahui

$\mathrm{a}=$ intersep

$\mathrm{b}=$ kemiringan yang dicari

\section{b. Metode Regresi Non-Linier}

Penyelesaian bentuk persamaan regresi nonlinier menggunakan metode LevenbergMarquat (LM). Metode ini menggabungkan metode Steepset Descent dan metode deret Taylor dasar, hal ini disebabkan karena tidak ada satupun metode optimasi yang benarbenar sempurna.

Secara umum permodelan persamaan regresi non-linier adalah:

$Y=f(x, a)$

Bentuk dasar persamaan yang digunakan dalam bentuk pertumbuhan ini adalah sebagai berikut :

- Logaritmatik $\quad: y=a \operatorname{Ln}(x)+b$

- Poynomial : $y=a x^{2}+b x+c$

- Eksponensial : $y=a e^{b x}$

- Power : $y=a x^{b}$

$y=$ peubah tak bebas, yaitu hasil yang ingin diketahui

$\mathrm{x}$ = peubah bebas, yaitu parameter yang

diketahui

a $=$ intersep

$\mathrm{b}=$ kemiringan yang dicari

\section{METODOLOGI}

Sebelum membuat Strategi Pengelolaan Potensi Sumber Daya Air, terlebih dahulu mengidentifikasi Potensi Sumber Daya Air dan Proyeksi Kebutuhan Air (Water Demand).

\subsection{Studi Potensi Sumber Daya Air}

Studi teoritis dan studi lapangan (survey) mengenai identifikasi Potensi Sumber Daya Air Kabupaten Pasuruan yang akan dililakukan adalah sebagai berikut, yaitu :

1. Melakukan survey dan investigasi untuk mendapatkan data (informasi) yang berkaitan dengan keperluan analisa dan kajian. Beberapa data sekunder yang dibutuhkan antara lain data klimatologi, data/ peta geologi, data/ peta hidrologi dll. Data primer dapat diperoleh dari : Survey Sumber -sumber Air, Survey / Pengukuran Geolistrik, Citra Satelit (LandSat/ RadarSat) dll.
2. Melakukan analisa dan kajian Posisi dan Sebaran Sumber Daya Air di Kabupaten Pasuruan.

3. Melakukan analisis dan kajian Kapasitas Sumber Air yang ada di Kabupaten Pasuran.

4. Melakukan analisis dan kaj ian Kualitas Air dari Sumber Daya Air yang ada di Kabupaten Pasuruan, termasuk identifikasi intrusi air laut bila ada.

\subsection{Studi Proyeksi Kebutuhan Air (Water Demand)}

Studi teoritis dan studi lapangan (survey) mengenai Proyeksi Kebutuhan Air (Water Demand) di Kabupaten Pasuruan yang akan dilakukan adalah sebagai berikut :

\section{a. Survey Kebutuhan Air Bersih}

Survey Kebutuhan Air Bersih meliputi Survey Kebutuhan Air Nyata (RWDS), yang akan dilaksanakan untuk 2 kelompok, yaitu:

- Kelompok Non Pelanggan PDAM

- Kelompok Pelanggan PDAM

\section{b. Survey Kebutuhan Air Industri}

Pada kegiatan survey Kebutuhan Air Industri, sampling dilakukan dengan menggunakan teknik pengambilan sampel secara multi stage random sampling. Tahapan penarikan sampel dilakukan untuk tiap-tiap kecamatan yang ada di Kabupaten Pasuruan dengan cara menghitung jumlah kebutuhan air untuk industri yang dipengaruhi oleh jumlah dan jenis industri.

\section{c. Survey Kebutuhan Air Pertanian}

Pada kegiatan survey Kebutuhan Air Pertanian, sampling dilakukan dengan menggunakan teknik pengambilan sampel secara multi stage random sampling. Tahapan penarikan sampel dilakukan untuk tiap-tiap kecamatan yang ada di Kabupaten Pasuruan dengan cara menghitung jumlah kebutuhan air untuk Pertanian yang dipengaruhi oleh Luas area pertanian, Jenis tanaman, J enis tanah (Perkolasi), Evaporasi.

\subsection{Strategi Pengelolaan Potensi Sumber Daya Air}

Strategi pengelolaan yang akan dilaksanakan antara lain :

- Tingkat kepentingan(Urgensi) penyediaan air.

- Kondisi Demand dan Suplai.

a. Tingkat kepentingan

Tingkat kepentingan (urgensi) penyediaan air secara alamiah dan menurut peraturan 
yang berlaku saat ini mempunyai urutan sebagai berikut :

- Air bersih untuk masyarakat

- Air industri

- Air pertanian

Dalam rangka pengembangan potensi sumber daya air di Kabupaten Pasuruan urutan diatas tetap akan dipakai sebagai acuan atau dasar.

\section{b. Kondisi Demand dan Suplai}

Dalam upaya mengetahui kondisi pemenuhan kebutuhan air, maka harus diketahui perbedaan antara kebutuhan (Demand) dan kapasiats yang ada (Suplai). Secara alamiah supali harus lebih besar dari Demand. Beberapa kondisi yang dapat dipakai sebagai acuan dalam perencanaan pengelolaan potensi sumber daya air di Kabupaten Pasuruan adalah :

- Kondisi Demand (Air Bersih dan Air Industri) dengan Suplai (Air Bawah Tanah)

- Kondisi Demand (Air Bersih, Air Industri dan Air Pertanian) dengan Suplai (Air Bawah Tanah dan Air Permukaan)

- Kondisi Demand (Air Bersih, Air Industri dan Air Pertanian) dengan Suplai (Air Bawah Tanah) paad musim kemarau

\subsection{Rencana Pengelolaan Air Permukaan}

Dari uraian diatas, air permukaan akan dimanfaatkan untuk pemenuhan kebutuhan air pertanian, dengan kondisi di misim kemarau kapasitas air tidak mencukupi untuk kebutuhan air pertanian maka perlu dibuat sarana penampung air hujan untuk menyediakan air di musim kemarau.

\subsection{Rencana Pengelolaan Air Bawah Tanah}

Dari uraian diatas, air bawah tanah akan dimanfaatkan untuk memenuhi kebutuhan air bersih dan kebutuhan air industri.

- Kebutuhan Air ( Water Demand ) Daerah Pengelolaan

Kebutuhan air pada daerah pengelolaan sangat dipengaruhi oleh strategi pengelolaan yang dipakai.

- Sumber Air

Sumber air yang memenuhi persyaratan kualitas air, kuantitas air dan kontinunitas air dan berdekatan dengan lokasi atau wilayah pengelolaan adalah sumber air umbulan yang terletak di daerah tangkapan air.

- Sistem Pengaliran
4. HASIL PENILITIAN

4.1 Potensi Sumber Daya Air

a. Kapasitas Air Permukaan

Kapasitas air permukaan per Daerah Tangkapan Air dapat dilihat pada Tabel 1.

b. Kapasitas Air Bawah Tanah

Kapasitas Air Bawah Tanah per Daerah Tangkapan Air ( Catchment Area) dapat dilihat pada Tabel 2.

\section{c. Cadangan Air Bawah Tanah}

Volume cadangan air bawah tanah di Kabupaten Pasuruan dalam bentuk Tabel ada pada Tabel 3.

Tabel 3 Volume Cadangan Air Bawah Tanah

\begin{tabular}{|l|l|r|}
\hline No & J enis Akuifer & \multicolumn{1}{|c|}{ Volume $\left(\mathrm{m}^{3}\right)$} \\
\hline 1. & Akuifer Bebas & 1.799 .785 .680 \\
\hline 2. & Akuifer Tertekan & 28.914 .040 \\
\hline & TOTAL & 1.828 .699 .720 \\
\hline
\end{tabular}

\subsection{Proyeksi Kebutuhan Air (Water Demand)}

\section{a. Kebutuhan Air Bersih}

Total kebutuhan air bersih per Kecamatan di Kabupaten Pasuruan dapat dilihat pada Tabel 4.

\section{b. Kebutuhan Air Industri}

Kebutuhan air industri per kecamatan di Kabupaten Pasuruan untuk 10 tahun mendatang pada Tabel 5.

\section{c. Kebutuhan Air Pertanian}

Total kebutuhan air pertanian per Kecamatan di Kabupaten Pasuruan dapat dilihat pada Tabel 6.

\section{d. Total Kebutuhan Air}

Total kebutuhan air yang meliputi kebutuhan air bersih untuk penduduk, air industri dan air pertanian per Kecamatan di Kabupaten Pasuruan dapat dilihat pada Tabel 7.

\subsection{Strategi Pengelolaan Potensi Sumber Daya Air \\ 4.3.1 Kondisi Demand dan Suplai} a. Kondisi Demand (Air Bersih dan Air Industri) dengan Suplai (Air Bawah Tanah) Kondisi Demand untuk air bersih dan air industri dengan suplai berasal dari air bawah tanah untuk Kabupaten Pasuruan dapat dilihat pada Tabel 8.

Dari Tabel 8. terlihat bahwa kebutuhan air bersih dan air industri di Kabupaten Pasuruan dapat dipenuhi oleh Air Bawah Tanah. 
b. Kondisi Demand (Air Bersih, Air Industri dan Air Pertanian) dengan Suplai (Air Bawah Tanah dan Air Permukaan)

Kondisi Demand untuk air bersih, air industri dan air pertaniaan dengan suplai berasal dari air bawah tanah dan air permukaan untuk Kabupaten Pasuruan dapat dilihat pada Tabel 9.

Dari Tabel 9. terlihat bahwa kebutuhan air bersih dan air industri di Kabupaten Pasuruan dapat dipenuhi oleh Air Bawah Tanah dan dan air permukaan.

c. Kondisi Demand (Air Bersih, Air Industri dan Air Pertanian) dengan Suplai (Air Bawah Tanah) paad musim kemarau

Kondisi Demand untuk air bersih,air industri dan air pertaniaan dengan suplai berasal dari air bawah tanah untuk Kabupaten Pasuruan di musim kemarau dapat dilihat pada Tabel 10.

Dari Tabel 10. terlihat bahwa di musim kemarau sumber daya air di Kabupaten Pasuruan tidak dapat memenuhi kebutuhan air yang ada di Kabupaten Pasuruan.

\subsubsection{Rencana Pengelolaan Air Permukaan} Kebutuhan atau volume sarana penampung air / reservoar ( waduk / dam / embung ) untuk Kabupaten Pasuruan dapat dilihat pada Tabel 11.

\subsubsection{Rencana Pengelolaan Air Bawah Tanah}

\section{a. Kebutuhan Air ( Water Demand ) Daerah Pengembangan}

Kebutuhan air pada daerah pengembangan sangat dipengaruhi oleh strategi pengembangan yang dipakai.

Strategi Pengembangan ada pada Tabel 12, sedangkan kebutuhan air untuk daerah pengembangan dapat dilihat pada

Tabel 13.

\section{b.Sumber Air}

Sumber air yang memenuhi persyaratan kualitas air, kuantitas air dan kontinunitas air dan berdekatan denagn lokasi atau wilayah pengembangan adalah sumber air umbulan yang terletak di daerah tangkapan air "sub- sub das Rejoso" dengan kapasitas di musim kemarau sebesar 2.464 liter/ detik, sehingga masih mencukupi Kebutuhan air bersih dan air industri sampai akhir periode perencanaan ( Tahun 2012 ) sebesar 1.627 liter/ detik.

\section{c. Sistem Pengaliran}

Sistem pengaliran yang direncanakan menggunakan yaitu pengaliran di bawah tekanan dengan memakai pompa.

Kapasiats dan head pompa untuk masing masing tahapan adalah sebagai berikut :

- Tahap Jangka Menengah (Tahun 2002 2007), kapasitas 890 liter/detik dan head 30 meter.

- Tahap Jangka Panjang (Tahun 2007 2012), kapasitas 1627 liter/ detik dan head 64 meter.

Tabel 1. Kapasitas Air Permukaan per Daerah Tangkapan Air

\begin{tabular}{|c|c|c|c|c|c|}
\hline No. & Nama DAS & $\mathrm{C}$ & $\begin{array}{c}\mathrm{I} \\
\mathrm{mm} / \mathrm{Jam}\end{array}$ & $\begin{array}{c}\mathrm{A} \\
\mathrm{m} 2\end{array}$ & $\begin{array}{c}\text { Ka pa sita s A ir Permuka a n } \\
\text { m } 3 \text { / Ta hun }\end{array}$ \\
\hline & & & & & \\
\hline 1. & Sub Sub DAS Kambeng & 0,671 & 1,571 & 42.849 .790 & 395.331 .892 \\
\hline 2. & Sub Sub DAS Kedunglarangan & 0,659 & 0,783 & 301.423 .963 & 1.361 .655 .144 \\
\hline 3. & Sub Sub DASMasangan & 0,654 & 0,531 & 65.027 .800 & 197.651 .435 \\
\hline 4. & Sub Sub DASWelang & 0,664 & 0,549 & 369.023 .700 & 1.178 .219 .785 \\
\hline 5. & Sub Sub DAS Petung dan Gembong & 0,652 & 0,538 & 248.269 .200 & 761.661 .959 \\
\hline 6. & Sub Sub DAS Re jo so & 0,652 & 0,332 & 281.581 .200 & 534.072 .896 \\
\hline 7. & Sub Sub DAS Laweyan & 0,653 & 0,386 & 200.710 .000 & 442.616 .637 \\
\hline 8. & Sub Sub DAS Bromo & 0,754 & 0,670 & 14.167 .730 & 62.666 .998 \\
\hline & Kapa sit & & & & 4.933 .876 .748 \\
\hline
\end{tabular}

Tabel 2. Kapasitas Air Bawah Tanah per Daerah Tangkapan Air.

\begin{tabular}{|c|c|c|c|c|c|}
\hline No. & Nama DAS & $1-\mathrm{C}$ & $\begin{array}{l}\text { R rata - ra ta } \\
\mathrm{m} m / \mathrm{Ta} \text { hun }\end{array}$ & $\begin{array}{c}\mathrm{A} \\
\mathrm{m} 2\end{array}$ & $\begin{array}{c}\text { Kapasitas A ir Bawah Ta na h } \\
\text { m } 3 \text { / Ta hun }\end{array}$ \\
\hline & & & & & \\
\hline 1. & Sub Sub DASKambeng & 0,330 & 1.540 & 42.849 .790 & 21.736 .209 \\
\hline 2. & Sub Sub DAS Kedunglarangan & 0,341 & 1.543 & 301.423 .963 & 158.687 .210 \\
\hline 3. & Sub Sub DASMasangan & 0,346 & 1.505 & 65.027 .800 & 33.854 .426 \\
\hline 4. & Sub Sub DASWelang & 0,336 & 1.384 & 369.023 .700 & 171.655 .950 \\
\hline 5. & Sub Sub DASPetung dan Gembong & 0,349 & 1.280 & 248.269 .200 & 110.747 .925 \\
\hline 6. & Sub Sub DAS Re jo so & 0,348 & 793 & 281.581 .200 & 77.730 .772 \\
\hline 7. & Sub Sub DAS Laweyan & 0,347 & 768 & 200.710 .000 & 53.468 .993 \\
\hline 8. & Sub Sub DAS Bromo & 0,246 & 592 & 14.167 .730 & 2.064 .952 \\
\hline & Kapas & tal & & & 629.946 .438 \\
\hline
\end{tabular}

J urnal APLIKASI: Media Informasi \& Komunikasi Aplikasi Teknik Sipil Terkini 
Tabel 4. Kebutuhan Air Bersih per Kecamatan

\begin{tabular}{|c|c|c|c|c|c|c|c|c|c|c|c|c|}
\hline \multirow[t]{2}{*}{ Io.] } & \multirow{2}{*}{ Kecamatan } & \multicolumn{11}{|c|}{ Kebutuhan Air ( $\mathrm{m}^{3} / \mathrm{T}$ ahun $)$} \\
\hline & & 2002 & 2003 & 2004 & 2005 & 2006 & 2007 & 2008 & 2009 & 2010 & 2011 & 2012 \\
\hline & & & & & & & & & & & & \\
\hline 1 & Purwodadi & $3,158,041$ & $3,208,957$ & $3,261,552$ & $3,315,833$ & $3,371,796$ & $3,429,440$ & $3,488,761$ & $3,549,765$ & $3,612,451$ & $3,676,813$ & $3,742,859$ \\
\hline 2 & Tutur & $3,059,643$ & $3,111,966$ & $3,168,135$ & $3,228,135$ & $3,291,987$ & $3,359,670$ & $3,431,194$ & $3,506,561$ & $3,585,767$ & $3,668,818$ & $3,755,702$ \\
\hline 3 & Puspo & $1,617,830$ & $1,646,305$ & $1,676,480$ & $1,708,359$ & $1,741,938$ & $1,777,223$ & $1,814,211$ & $1,852,905$ & $1,893,299$ & $1,935,403$ & $1,979,202$ \\
\hline 4 & Tosari & $1,047,714$ & $1,071,133$ & $1,096,616$ & $1,124,220$ & $1,153,965$ & $1,185,914$ & $1,220,112$ & $1,256,617$ & $1,295,503$ & $1,336,837$ & $1,380,704$ \\
\hline 5 & Lumbang & $1,910,452$ & $1,943,488$ & $1,979,949$ & $2,019,835$ & $2,063,140$ & $2,109,871$ & $2,160,022$ & $2,213,603$ & $2,270,599$ & $2,331,025$ & $2,394,865$ \\
\hline 6 & Pasrepan & $3,441,767$ & $3,548,154$ & $3,663,412$ & $3,787,530$ & $3,920,520$ & $4,062,382$ & $4,213,104$ & $4,372,692$ & $4,541,158$ & $4,718,478$ & $4,904,676$ \\
\hline 7 & Kejayan & $3,988,101$ & $4,037,541$ & $4,164,577$ & $4,261,211$ & $4,363,443$ & $4,471,266$ & $4,584,689$ & $4,703,708$ & $4,828,323$ & $4,958,532$ & $5,094,338$ \\
\hline 8 & Wonorejo & $3,513,830$ & $3,654,469$ & $3,812,312$ & $3,987,357$ & $4,179,614$ & $4,389,083$ & $4,615,753$ & $4,859,636$ & $5,120,720$ & $5,399,015$ & $5,694,523$ \\
\hline 9 & Purwosari & $4,476,629$ & $4,648,482$ & $4,841,238$ & $5,054,895$ & $5,289,567$ & $5,545,085$ & $5,821,563$ & $6,118,998$ & $6,437,336$ & $6,776,577$ & $7,136,777$ \\
\hline 10 & Prigen & $4,731,939$ & $4,936,008$ & $5,165,273$ & $5,419,788$ & $5,699,551$ & $6,004,510$ & $6,334,720$ & $6,690,124$ & $7,070,780$ & $7,476,630$ & $7,907,675$ \\
\hline 11 & Sukorejo & $5,130,179$ & $5,502,780$ & $5,923,553$ & $6,392,486$ & $6,909,580$ & $7,474,901$ & $8,088,328$ & $8,749,914$ & $9,459,728$ & $10,217,648$ & $11,023,795$ \\
\hline 12 & Pandaan & $5,778,485$ & $6,041,949$ & $6,327,835$ & $6,636,330$ & $6,967,306$ & $7,320,875$ & $7,697,034$ & $8,095,854$ & $8,517,343$ & $8,961,594$ & $9,428,607$ \\
\hline 13 & Gempol & $6,566,280$ & $6,943,668$ & $7,360,786$ & $7,817,470$ & $8,313,887$ & $8,849,870$ & $9,425,530$ & $10,040,865$ & $10,695,822$ & $11,390,456$ & $12,124,711$ \\
\hline 14 & Beji & $4,400,134$ & $4,618,947$ & $4,856,593$ & $5,113,019$ & $5,388,278$ & $5,682,261$ & $5,995,078$ & $6,326,730$ & $6,677,105$ & $7,046,314$ & $7,434,302$ \\
\hline 15 & Bangil & $4,743,435$ & $4,884,208$ & $5,038,783$ & $5,207,158$ & $5,389,391$ & $5,585,369$ & $5,795,148$ & $6,018,729$ & $6,256,055$ & $6,507,237$ & $6,772,220$ \\
\hline 16 & Rembang & $3,746,000$ & $3,919,767$ & $4,113,112$ & $4,326,053$ & $4,558,581$ & $4,810,701$ & $5,082,399$ & $5,373,994$ & $5,684,575$ & $6,015,035$ & $6,365,086$ \\
\hline 17 & Kraton & $5,197,272$ & $5,411,540$ & $5,645,078$ & $5,897,886$ & $6,169,908$ & $6,461,199$ & $6,771,706$ & $7,101,483$ & $7,450,474$ & $7,818,737$ & $8,206,267$ \\
\hline 18 & Pohjentrek & $1,752,749$ & $1,884,833$ & $2,032,984$ & $2,197,208$ & $2,377,505$ & $2,573,869$ & $3,786,301$ & $3,014,811$ & $3,259,383$ & $3,520,034$ & $3,796,752$ \\
\hline 19 & Gondangwetan & $3,028,073$ & $3,049,435$ & $3,066,356$ & $3,078,840$ & $3,086,881$ & $3,090,491$ & $3,089,653$ & $3,084,384$ & $3,074,673$ & $3,060,525$ & $3,041,933$ \\
\hline 20 & Rejoso & $2,490,479$ & $2,602,395$ & $2,728,730$ & $2,869,486$ & $3,024,668$ & $3,194,275$ & $3,378,303$ & $3,576,751$ & $3,789,625$ & $4,016,918$ & $4,258,634$ \\
\hline 21 & Winongan & $2,649,578$ & $2,723,026$ & $2,804,441$ & $2,893,818$ & $2,991,158$ & $3,096,459$ & $3,209,729$ & $3,330,960$ & $3,460,153$ & $3,597,310$ & $3,742,433$ \\
\hline 22 & Grati & $4,272,174$ & $4,383,545$ & $4,507,504$ & $4,644,055$ & $4,793,190$ & $4,954,913$ & $5,129,239$ & $5,361,202$ & $5,515,761$ & $5,727,927$ & $5,952,692$ \\
\hline 23 & Lekok & $3,962,963$ & $4,226,125$ & $4,524,055$ & $4,856,753$ & $5,224,221$ & $5,626,458$ & $6,063,465$ & $6,535,239$ & $7,041,727$ & $7,583,040$ & $8,159,066$ \\
\hline 24 & Nguling & $3,371,883$ & $3,398,519$ & $3,423,705$ & $3,447,438$ & $3,469,727$ & $3,490,561$ & $3,509,951$ & $3,527,887$ & $3,544,373$ & $3,559,410$ & $3,572,992$ \\
\hline & & & & & & & & & & & & \\
\hline & $a 1\left(\mathrm{~m}^{3} /\right.$ Thahun $)$ & $88,035,632$ & $91,433,239$ & $95,183,059$ & $99,285,165$ & $103,739,803$ & $108,546,646$ & $113,705,992$ & $119,218,113$ & $125,082,734$ & $131,300,314$ & $137,870,812$ \\
\hline & al (liter / detik) & $2,791.59$ & $2,899.33$ & $3,018.24$ & $3,148.31$ & $3,289.57$ & $3,441.99$ & $3,605.59$ & $3,780.38$ & $3,966.35$ & $4,163.5$ & $4,371.85$ \\
\hline
\end{tabular}

Tabel 5. Kebutuhan Air Untuk Industri per Kecamatan

\begin{tabular}{|c|c|c|c|c|c|c|c|c|c|c|c|c|}
\hline \multirow{2}{*}{ No. } & \multirow{2}{*}{ Kecamatan } & \multicolumn{11}{|c|}{ Kebutuhan Air $\left(\mathrm{m}^{3} / \mathrm{T}\right.$ ahun $)$} \\
\hline & & 2002 & 2003 & 2004 & 2005 & 2006 & 2007 & 2008 & 2009 & 2010 & 2011 & 2012 \\
\hline & & & & & & & & & & & & \\
\hline 1 & Purwodadi & 385,440 & 390,378 & 395,316 & 400,255 & 405,194 & 410,132 & 415,072 & 420,011 & 424,949 & 429,884 & 434,876 \\
\hline 2 & Tutur & 148,920 & 150,828 & 152,736 & 154,644 & 156,552 & 158,460 & 160,369 & 162,277 & 164,185 & 166,092 & 168,020 \\
\hline 3 & Puspo & 177,938 & 180,218 & \begin{tabular}{ll|}
182,497 \\
\end{tabular} & 184,777 & 187,058 & 189,337 & 191,617 & 193,898 & 196,177 & 198,455 & 200,760 \\
\hline 4 & Tosari & 63,510 & 64,324 & 65,137 & 65,951 & 66,765 & 67,579 & 68,392 & 69,206 & 70,020 & 70,833 & 71,656 \\
\hline 5 & Lumbang & 396,390 & 401,469 & 406,546 & 411,626 & 416,705 & 421,784 & 426,863 & 431,943 & 437,021 & 442,096 & 447,231 \\
\hline 6 & Pasrepan & 436,358 & 441,949 & 447,538 & 453,130 & 458,722 & 464,312 & 469,904 & 475,496 & 481,086 & 486,673 & 492,325 \\
\hline 7 & Kejayan & 333,975 & 338,254 & 342,532 & 346,812 & 351,092 & 355,370 & 359,650 & 363,930 & 368,208 & 372,485 & 376,810 \\
\hline 8 & Wonorejo & 343,283 & 347,681 & 352,079 & 356,478 & 360,877 & 365,275 & 369,674 & 374,073 & 378,471 & 382,866 & 387,312 \\
\hline 9 & Purwosari & 491,655 & 497,954 & 504,252 & 510,552 & 516,853 & 523,152 & 529,452 & 535,753 & 542,051 & 548,346 & 554,714 \\
\hline 10 & Prigen & 174,105 & 176,336 & 178,566 & 180,797 & 183,028 & 185,259 & 187,490 & 189,721 & 191,951 & 194,181 & 196,436 \\
\hline 11 & Sukorejo & 344,925 & 349,344 & 353,763 & 358,183 & 362,603 & 367,022 & 371,442 & 375,862 & 380,281 & \begin{tabular}{|l|}
384,697 \\
\end{tabular} & 389,165 \\
\hline 12 & Pandaan & 331,238 & 335,482 & 339,725 & 343,970 & 348,214 & 352,458 & 356,703 & 360,947 & 365,191 & 369,432 & 373,722 \\
\hline 13 & Gempol & 524,505 & 531,225 & 537,944 & 544,665 & 551,386 & 558,106 & 564,828 & 571,549 & 578,268 & 584,984 & 591,778 \\
\hline 14 & Beji & 326,858 & 331,046 & 335,233 & 339,421 & 343,610 & 347,797 & 351,986 & 356,175 & 360,362 & 364,547 & 368,781 \\
\hline 15 & Bangil & 924,728 & 936,576 & 948,421 & 960,271 & 972,121 & 983,968 & 995,819 & $1,007,669$ & $1,019,516$ & $1,031,356$ & $1,043,333$ \\
\hline 16 & Rembang & 653,168 & 661,536 & 669,904 & 678,273 & 686,644 & 695,012 & 703,382 & 711,752 & 720,120 & 728,483 & 736,943 \\
\hline 17 & Kraton & 464,828 & 470,783 & 476,738 & 482,694 & 488,651 & 494,606 & 500,563 & 506,519 & 512,474 & 518,426 & 524,447 \\
\hline 18 & Pohjentrek & 254,040 & 257,295 & 260,549 & 263,804 & 267,060 & 270,314 & 273,570 & 276,825 & 280,080 & 283,333 & 286,623 \\
\hline 19 & Gondangwetan & 231,045 & 234,005 & 236,965 & 239,926 & 242,886 & 245,846 & 248,807 & 251,768 & 254,728 & 257,686 & 260,679 \\
\hline 20 & Rejoso & 336,713 & 341,027 & 345,340 & 349,655 & 353,970 & 358,284 & 362,599 & 366,913 & 371,227 & 375,538 & 379,900 \\
\hline 21 & Winongan & 211,335 & 214,043 & 216,750 & 219,458 & 222,166 & 224,874 & 227,582 & 230,290 & 232,998 & 235,703 & 238,441 \\
\hline 22 & Grati & 263,348 & 266,722 & 270,096 & 273,470 & 276,845 & 280,219 & 283,593 & 286,968 & 290,342 & 293,714 & 297,125 \\
\hline 23 & Lekok & 120,998 & 122,548 & 124,098 & 125,649 & 127,199 & 128,749 & 130,300 & 131,851 & 133,401 & 134,950 & 136,517 \\
\hline 24 & Nguling & 180,128 & 182,436 & 184,743 & 187,051 & 189,360 & \begin{tabular}{|l|}
191,667 \\
\end{tabular} & 193,976 & 196,284 & 198,592 & 200,898 & 203,231 \\
\hline & & & & & & & & & & & & \\
\hline & $\mathrm{al}\left(\mathrm{m}^{3} / \mathrm{Tahun}\right)$ & $8,119,425$ & $8,223,450$ & $8,327,475$ & $8,431,500$ & $8,535,525$ & $8,639,550$ & $8,743,575$ & $8,847,600$ & $8,951,625$ & $9,055,650$ & $9,159,675$ \\
\hline & al (liter / detik) & 257.47 & 260.76 & 264.06 & 267.36 & 270.66 & 273.96 & 277.26 & 280.56 & 283.85 & 287.15 & 290.45 \\
\hline
\end{tabular}


Tabel 6. Kebutuhan Air Pertanian per Kecamatan

\begin{tabular}{|c|c|c|c|c|c|c|c|c|c|c|c|c|}
\hline \multirow{2}{*}{ No. } & \multirow{2}{*}{ Kecamatan } & \multicolumn{11}{|c|}{ Kebutuhan Air (m/Takun) } \\
\hline & & 2002 & 2003 & 2004 & 2005 & 2006 & 2007 & 2008 & 2009 & 2010 & 2011 & 2012 \\
\hline & & & & & & & & & & & & \\
\hline 1 & Furwodadi & $86,135,918$ & $87,925,196$ & $89,693,046$ & $1,438,609$ & $93,163,057$ & $94,865,900$ & $96,546,779$ & $98,205,470$ & $99,842,893$ & $101,458,106$ & $103,051,279$ \\
\hline 2 & Tutur & $22,295,381$ & $22,758,517$ & $23,216,106$ & $23,667,927$ & $24,114,282$ & $24,555,045$ & $24,990,123$ & $25,419,458$ & $25,843,288$ & $26,261,369$ & $26,673,745$ \\
\hline 3 & Fuspo & $33,515,778$ & $34,211,992$ & $34,899,868$ & $35,579,073$ & $36,250,062$ & $36,912,644$ & $37,566,679$ & $38,212,081$ & $38,849,209$ & $39,477,693$ & $40,097,602$ \\
\hline 4 & Tosari & $16,653,083$ & $16,999,013$ & $17,340,800$ & $17,678,278$ & $18,011,675$ & $18,340,894$ & $18,665,866$ & $18,986,549$ & $19,303,120$ & $19,615,397$ & $19,923,413$ \\
\hline 5 & Lumbang & $67,342,966$ & $68,741,863$ & $70,124,007$ & $71,488,727$ & $72,836,939$ & $74,168,259$ & $75,482,408$ & $76,779,208$ & $78,059,382$ & $79,322,192$ & $80,567,769$ \\
\hline 6 & Pasrepan & $69,103,111$ & $70,538,571$ & $71,956,840$ & $73,357,230$ & $74,740,680$ & $76,106,797$ & $77,455,293$ & $78,785,989$ & $80,099,623$ & $81,395,438$ & $82,673,571$ \\
\hline 7 & Kejayan & $151,856,172$ & $155,010,638$ & $158,127,328$ & $161,204,726$ & $164,244,899$ & $167,246,983$ & $170,210,345$ & $173,134,588$ & $176,021,338$ & $178,868,931$ & $181,677,668$ \\
\hline 8 & Wonorejo & $92,206,530$ & $94,121,911$ & $96,014,354$ & $97,882,939$ & $99,728,921$ & $101,551,776$ & $103,351,119$ & $105,126,709$ & $106,879,533$ & $108,608,582$ & $110,314,037$ \\
\hline 9 & Purwosari & $108,382,580$ & $110,633,982$ & $112,858,421$ & $115,054,817$ & $117,224,646$ & $119,367,288$ & $21,482,295$ & $123,569,382$ & $125,629,709$ & $127,662,090$ & $129,666,738$ \\
\hline 10 & Prizen & 738,064 & $52,812,805$ & $53,874,674$ & $54,923,157$ & $55,958,958$ & $56,981,781$ & $57,991,411$ & $58,987,714$ & $59,971,242$ & $60,941,430$ & $61,898,379$ \\
\hline 11 & Sukorejo & $110,657,710$ & $112,956,372$ & $115,227,506$ & $117,470,009$ & $119,685,385$ & $121,873,006$ & $124,032,410$ & $126,163,308$ & $128,266,885$ & $130,341,929$ & $132,388,657$ \\
\hline 12 & Pandaan & 605,991 & $94,529,670$ & $96,430,311$ & $98,306,992$ & $100,160,971$ & $101,991,723$ & $103,798,861$ & $105,582,143$ & $107,342,561$ & $109,079,101$ & 91,944 \\
\hline 13 & Gempol & $66,719,013$ & $68,104,949$ & $69,474,287$ & $70,826,362$ & $72,162,082$ & $73,481,067$ & $74,783,040$ & $76,067,826$ & $77,336,138$ & $78,587,247$ & $79,821,284$ \\
\hline 14 & Beji & $75,710,124$ & $77,282,830$ & $78,836,701$ & $80,370,983$ & $81,886,706$ & $83,383,439$ & $84,860,866$ & $86,318,791$ & $87,758,022$ & $89,177,732$ & $90,578,069$ \\
\hline 15 & Bangil & $80,710,420$ & $82,386,995$ & $84,043,493$ & $85,679,107$ & $87,294,936$ & $88,890,521$ & $0,465,526$ & $92,019,739$ & $93,554,025$ & $95,067,500$ & $96,560,322$ \\
\hline 16 & Rembang & $171,498,314$ & $175,060,801$ & $178,580,625$ & $182,056,076$ & $185,489,486$ & $188,879,880$ & $192,226,544$ & $195,529,030$ & $198,789,172$ & $202,005,093$ & $205,177,132$ \\
\hline 17 & Kraton & $160,531,501$ & $163,866,178$ & $167,160,919$ & $170,414,125$ & $173,627,979$ & $176,801,567$ & $179,934,222$ & $183,025,523$ & $186,077,189$ & $189,087,461$ & $192,056,657$ \\
\hline 18 & Pohjentrek & $55,255,118$ & $56,402,917$ & $57,536,971$ & $58,656,728$ & $59,762,940$ & $60,855,293$ & $61,933,556$ & $62,997,585$ & $64,047,972$ & $65,084,111$ & $66,106,111$ \\
\hline 19 & Gondangwetan & $90,395,073$ & $92,272,825$ & $94,128,090$ & $95,959,965$ & $97,769,682$ & $99,556,725$ & $101,320,719$ & $103,061,427$ & $104,779,816$ & $106,474,896$ & $108,146,846$ \\
\hline 20 & Rejoso & $88,103,223$ & $89,933,367$ & $91,741,594$ & $93,527,025$ & $95,290,859$ & $97,032,594$ & $98,751,864$ & $100,448,438$ & $102,123,259$ & $103,775,363$ & $105,404,923$ \\
\hline 21 & Winongan & $86,346,895$ & $88,140,555$ & $89,912,735$ & $91,662,574$ & $93,391,246$ & $95,098,260$ & $96,783,256$ & $98,446,009$ & $100,087,443$ & $101,706,612$ & $103,303,687$ \\
\hline 22 & Grati & $94,119,244$ & $96,074,357$ & $98,006,057$ & $99,913,403$ & $101,797,678$ & $103,658,346$ & $105,495,014$ & $107,307,437$ & $109,096,621$ & $110,861,537$ & $112,602,369$ \\
\hline 23 & Lekok & $52,606,701$ & $53,699,486$ & $54,779,183$ & $55,845,269$ & $56,898,460$ & $57,938,455$ & $58,965,036$ & $59,978,066$ & $60,978,107$ & $61,964,583$ & $62,937,598$ \\
\hline 24 & Nguling & $6,371,738$ & $128,996,823$ & $131,590,472$ & $134,151,422$ & $136,681,395$ & $139,179,670$ & $141,645,722$ & $144,079,220$ & $146,481,517$ & $148,851,228$ & $151,188,604$ \\
\hline & & & & & & & & & & & & \\
\hline & $1(\mathrm{~m} / \mathrm{Tahum})$ & $2,050,860,647$ & $2,126,774,401$ & $2,209,678,910$ & $2,299,546,982$ & $283,735,690$ & $2,471,807,351$ & $2,566,623,062$ & $2,668,422,916$ & $2,768,256,878$ & $2,866,869,547$ & $2,955,009,359$ \\
\hline rota & 1 (liter / detik ) & 032.36 & $67,439.57$ & $70,068.46$ & $72,918.16$ & $75,556.05$ & $78,380.50$ & $81,387.08$ & $84,615.14$ & $87,780.85$ & $90,907.84$ & 93,702 . \\
\hline
\end{tabular}

Tabel 7. Total Kebutuhan Air Kabupaten Pasuruan

\begin{tabular}{|c|c|c|c|c|c|c|c|c|c|c|c|c|}
\hline \multirow{2}{*}{ No. } & \multirow{2}{*}{ Kecamatan } & \multicolumn{11}{|c|}{ Kebutuhan Air ( $m / T_{a}$ ann $)$} \\
\hline & & 2002 & 2003 & 2004 & 2005 & 2006 & 2007 & 2008 & 2009 & 2010 & 2011 & 2012 \\
\hline & & & & & & & & & & & & \\
\hline 1 & Imodadi & $9,679,399$ & $1,524,450$ & $93,349,696$ & $5,154,836$ & $96,940,037$ & $98,705,149$ & $100,450,142$ & $02,174,868$ & $103,879,547$ & $105,564,049$ & $107,228,34$ \\
\hline 2 & Tutur & $25,503,944$ & $26,028,658$ & $6,547,741$ & 1,105 & $7,568,798$ & $8,070,779$ & 7,038 & $8,057,533$ & 342,327 & $0,021,383$ & $30,494,691$ \\
\hline 3 & Puspo & $35,311,545$ & $36,038,040$ & $36,756,736$ & $37,467,516$ & $38,170,444$ & $38,865,462$ & $39,552,559$ & $40,231,675$ & $40,902,898$ & $1,566,176$ & $42,221,496$ \\
\hline 4 & Tosari & $17,764,307$ & $18,129,787$ & $18,491,344$ & $18,848,919$ & $19,202,544$ & $19,552,189$ & $19,897,849$ & $20,239,495$ & $20,577,169$ & $20,910,847$ & $21,240,521$ \\
\hline 5 & umbang & $69,649,808$ & $71,082,773$ & $72,500,357$ & $3,902,325$ & $75,288,807$ & $76,659,687$ & $78,014,942$ & $9,354,456$ & $80,678,401$ & $1,986,675$ & $83,279,253$ \\
\hline 6 & Pasrepan & $72,981,235$ & $74,482,740$ & $75,968,128$ & $77,437,154$ & $78,889,954$ & $80,326,404$ & $81,746,482$ & $83,150,067$ & $84,537,338$ & $85,908,188$ & $87,262,591$ \\
\hline 7 & Kejayan & $156,178,248$ & $159,391,437$ & $162,570,135$ & $165,713,818$ & $168,822,777$ & $171,896,750$ & $174,935,686$ & $177,939,327$ & $180,908,055$ & $183,841,645$ & $186,740,039$ \\
\hline 8 & Tonorejo & $; 063,643$ & $, 040,043$ & $9,995,227$ & $101,928,874$ & $103,841,163$ & $105,731,933$ & $107,601,151$ & $109,448,660$ & $111,274,694$ & $113,079,115$ & $114,861,88$ \\
\hline 9 & \begin{tabular}{|l|} 
Purnosari \\
\end{tabular} & $113,350,864$ & $115,682,928$ & $117,989,960$ & $120,271,578$ & $122,527,995$ & $124,759,020$ & $126,964,615$ & $129,144,594$ & 99,234 & 28,371 & $135,531,964$ \\
\hline 10 & Prizen & $56,644,109$ & $57,809,497$ & $58,962,375$ & $0,102,554$ & $61,230,139$ & $62,345,034$ & $63,447,223$ & $64,536,610$ & $65,613,334$ & $66,677,315$ & $67,728,530$ \\
\hline 11 & Sukorejo & $6,132,814$ & $118,522,114$ & $120,885,766$ & $23,223,382$ & $125,535,178$ & $127,820,958$ & $130,080,685$ & $32,314,167$ & $134,521,688$ & $136,703,080$ & 858,30 \\
\hline 12 & Pandaan & 715,714 & $100,746,677$ & $102,755,839$ & $104,742,869$ & $106,707,952$ & $108,650,921$ & $110,571,743$ & $112,470,257$ & $114,346,704$ & 0,940 & 032,930 \\
\hline 13 & Gempol & $73,809,789$ & $75,328,341$ & $76,830,593$ & $78,316,296$ & $79,785,589$ & $81,238,348$ & $82,674,548$ & $84,094,068$ & $85,497,088$ & $86,883,501$ & $88,253,281$ \\
\hline 14 & Beji & 437,115 & $82,092,017$ & $83,729,154$ & 8,258 & $86,949,478$ & $88,532,679$ & $90,097,834$ & 44,811 & 73,808 & $4,684,706$ & $96,177,47$ \\
\hline 15 & Bangil & 378,852 & $88,155,998$ & $89,914,068$ & $91,652,772$ & $93,372,271$ & $95,072,420$ & $96,753,190$ & $98,414,440$ & $100,056,380$ & $101,678,886$ & $103,281,925$ \\
\hline 16 & Rembang & $175,897,481$ & $179,516,370$ & $183,096,414$ & $186,637,022$ & $190,138,521$ & $193,600,618$ & $197,023,253$ & $200,406,137$ & $203,749,700$ & $207,053,688$ & $210,318,036$ \\
\hline 17 & Kraton & $166,193,601$ & $169,612,844$ & $172,995,385$ & $176,340,665$ & $179,648,994$ & $182,920,095$ & $186,153,911$ & $189,350,168$ & $192,509,274$ & $195,630,988$ & $198,715,2$ \\
\hline 18 & Pohjentrek & $57,261,907$ & $58,440,005$ & $59,605,458$ & $60,758,072$ & $61,897,955$ & $63,025,010$ & $64,139,220$ & $65,240,488$ & $66,328,957$ & $67,404,541$ & $68,467,222$ \\
\hline 19 & Gondangwetan & $93,654,191$ & $95,581,019$ & $97,487,164$ & $99,372,312$ & $101,236,637$ & $103,079,982$ & $104,902,317$ & $106,703,487$ & $108,483,721$ & $110,242,884$ & $111,980,941$ \\
\hline 20 & Rejoso & $90,930,414$ & $92,801,203$ & $94,651,911$ & $96,482,233$ & $98,292,337$ & $100,082,072$ & $101,851,407$ & $103,600,193$ & $105,328,652$ & $107,036,653$ & $108,724,161$ \\
\hline 21 & Winongan & $89,207,808$ & $91,043,157$ & $92,858,804$ & $94,654,452$ & $96,430,265$ & $98,186,095$ & $99,921,912$ & $101,637,568$ & $103,333,283$ & $105,008,926$ & $106,664,467$ \\
\hline 22 & Grati & $98,654,765$ & $100,684,474$ & $102,692,396$ & $104,678,199$ & $106,642,068$ & $108,583,837$ & $110,503,474$ & $112,400,816$ & $114,276,104$ & $116,129,195$ & $117,960,054$ \\
\hline 23 & Lekok & $56,690,662$ & $57,857,007$ & $59,010,833$ & $60,151,949$ & $61,280,461$ & $62,396,273$ & $63,499,367$ & $64,589,649$ & $65,667,259$ & $66,732,113$ & $67,784,192$ \\
\hline 24 & Nguling & $29,923,748$ & $132,596,780$ & $135,241,120$ & $137,856,331$ & $140,442,655$ & $142,999,876$ & $145,527,948$ & $148,026,659$ & $150,496,326$ & $152,936,762$ & $155,347,91$ \\
\hline & 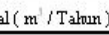 & $2,147,015,703$ & $2,226,431,090$ & $2,313,189,444$ & $1,407,263,647$ & $2,495,011,017$ & $2,588,993,547$ & $2,689,072,628$ & $2,796,488,629$ & $2,902,291,236$ & $3,007,225,510$ & $1,102,039,046$ \\
\hline & $\mathrm{al}($ liter $/$ detik ) & $68,081.42$ & $70,599.67$ & $73,350.76$ & $76,333.83$ & $79,116.28$ & $82,096.45$ & $85,269.93$ & $88,676.07$ & $92,031.05$ & $95,358.50$ & Nor \\
\hline
\end{tabular}


Tabel 8. Kebutuhan Air Bersih dan Kebutuhan Air Industri dengan Kapasitas Air Bawah Tanah

\begin{tabular}{|c|c|c|c|c|c|c|c|c|c|c|c|c|}
\hline \multirow[b]{2}{*}{ No. } & \multirow[b]{2}{*}{ Uraian } & \multicolumn{11}{|c|}{$\mathrm{m}^{3}$} \\
\hline & & 2002 & 2003 & 2004 & 2005 & 2006 & 2007 & 2008 & 2009 & 2010 & 2011 & 2012 \\
\hline & & & & & & & & & & & & \\
\hline \multirow[t]{5}{*}{ I } & KEBUTUHAN AIR & & & & & & & & & & & \\
\hline & a. Bersih & $88,035,632$ & $91,433,239$ & 95,183,059 & $99,285,165$ & $103,739,803$ & $108,546,646$ & $113,705,992$ & $119,218,113$ & $125,082,734$ & $131,300,314$ & $137,870,812$ \\
\hline & b. Industri & $8,119,425$ & $8,223,450$ & $8,327,475$ & $8,431,500$ & $8,535,525$ & $8,639,550$ & $8,743,575$ & $8,847,600$ & $8,951,625$ & $9,055,650$ & $9,159,675$ \\
\hline & TOTAL KEBUTUHAN & $96,155,057$ & 99,656,689 & $103,510,534$ & $107,716,665$ & $112,275,328$ & $117,186,196$ & $122,449,567$ & $128,065,713$ & $134,034,359$ & $140,355,964$ & $147,030,487$ \\
\hline & & & & & & & & & & & & \\
\hline II & Kapasitas Air Bawah Tanah & $615,664,830$ & $615,664,830$ & $615,664,830$ & $615,664,830$ & $615,664,830$ & $615,664,830$ & $615,664,830$ & $615,664,830$ & $615,664,830$ & $615,664,830$ & $615,664,830$ \\
\hline & & & & & & & & & & & & \\
\hline III & Demand/Sulpai & 0.16 & 0.16 & 0.17 & 0.17 & 0.18 & 0.19 & 0.20 & 0.21 & 0.22 & 0.23 & 0.24 \\
\hline
\end{tabular}

Tabel 9. Tabel Total Kebutuhan dan Kapasitas Air

\begin{tabular}{|c|c|c|c|c|c|c|c|c|c|c|c|c|}
\hline \multirow[b]{2}{*}{ No. } & \multirow[b]{2}{*}{ Uraian } & \multicolumn{11}{|c|}{$\mathrm{m}$} \\
\hline & & 2002 & 2003 & 2004 & 2005 & 2006 & 2007 & 2008 & 2009 & 2010 & 2011 & 2012 \\
\hline & & & & & & & & & & & & \\
\hline \multirow[t]{5}{*}{$I$} & KEBUTUHAN AIR & & & & & & & & & & & \\
\hline & a. Bersih & $88,035,632$ & $91,433,239$ & $95,183,059$ & $99,285,165$ & $103,739,803$ & $108,546,646$ & $113,705,992$ & $119,218,113$ & $125,082,734$ & $131,300,314$ & $137,870,812$ \\
\hline & b. Industri & $8,119,425$ & $8,223,450$ & $8,327,475$ & $8,431,500$ & $8,535,525$ & $8,639,550$ & $8,743,575$ & $8,847,600$ & $8,951,625$ & $9,055,650$ & $9,159,675$ \\
\hline & c. Pertanian & $2,050,860,647$ & $2,126,774,401$ & $2,209,678,910$ & $2,299,546,982$ & $2,382,735,690$ & $2,471,807,351$ & $2,566,623,062$ & $2,668,422,916$ & $2,768,256,878$ & $2,866,869,547$ & $2,955,009,846$ \\
\hline & TOTAL KEBUTUHAN & $2,147,015,704$ & $2,226,431,090$ & $2,313,189,444$ & $2,407,263,647$ & $2,495,011,018$ & $2,588,993,547$ & $2,689,072,629$ & $2,796,488,629$ & $2,902,291,23 ?$ & $3,007,225,511$ & $3,102,040,333$ \\
\hline & & & & & & & & & & & & \\
\hline \multirow[t]{4}{*}{ II } & Kapasitas Air & & & & & & & & & & & \\
\hline & a. Bawah Tanah & $615,664,830$ & $615,664,830$ & \begin{tabular}{|l|}
$615,664,830$ \\
\end{tabular} & $615,664,830$ & $615,664,830$ & $615,664,830$ & $615,664,830$ & $615,664,830$ & $615,664,830$ & $615,664,830$ & $615,664,830$ \\
\hline & b. Permoukaan & $4,878,173,230$ & $4,878,173,230$ & $4,878,173,230$ & $4,878,173,230$ & $4,878,173,230$ & $4,878,173,230$ & $4,878,173,230$ & $4,878,173,230$ & $4,878,173,230$ & $4,878,173,230$ & $4,878,173,230$ \\
\hline & TOTAL KAPASITAS & $5,493,838,060$ & $5,493,838,060$ & $5,493,838,060$ & $5,493,838,060$ & $5,493,838,060$ & $5,493,838,060$ & $5,493,838,060$ & $5,493,838,060$ & $5,493,838,060$ & $5,493,838,060$ & $5,493,838,060$ \\
\hline & & & & & & & & & & & & \\
\hline III & DemandSulpai & 0.39 & 0.41 & 0.42 & 0.44 & 0.45 & 0.47 & 0.49 & 0.51 & 0.53 & 0.55 & 0.56 \\
\hline
\end{tabular}

Tabel 10. Kebutuhan Air dan Kapasitas pada Musim Kemarau

\begin{tabular}{|c|c|c|c|c|c|c|c|c|c|c|c|c|}
\hline \multirow[b]{2}{*}{ №. } & \multirow[b]{2}{*}{ Uraian } & \multicolumn{11}{|c|}{$\mathrm{m}$} \\
\hline & & 2002 & 2003 & 2004 & 2005 & 2006 & 2007 & 2008 & 2009 & 2010 & 2011 & 2012 \\
\hline & & & & & & & & & & & & \\
\hline \multirow[t]{5}{*}{$\mathrm{I}$} & KEBUTUHAN AIR & & & & & & & & & & & \\
\hline & a. Bersih & $44,017,816$ & $45,716,620$ & $47,591,529$ & $49,642,582$ & $51,869,901$ & $54,273,323$ & $56,852,996$ & $59,609,057$ & $62,541,367$ & $65,650,157$ & $68,935,406$ \\
\hline & b. Industri & $4,059,713$ & $4,111,725$ & $4,163,738$ & $4,215,750$ & $4,267,763$ & $4,319,775$ & $4,371,788$ & $4,423,800$ & $4,475,813$ & $4,527,825$ & $4,579,838$ \\
\hline & c. Pertanian & $1,025,430,323$ & $1,063,387,200$ & $1,104,839,455$ & $1,149,773,491$ & $1,191,367,845$ & $1,235,903,675$ & $1,283,311,531$ & $1,334,211,458$ & $1,451,145,618$ & $1,384,128,439$ & $1,477,504,680$ \\
\hline & TOTAL KEBUTUHAN & $1,073,507,852$ & $1,113,215,545$ & $1,156,594,722$ & $1,203,631,823$ & $1,247,505,509$ & $1,294,496,773$ & $1,344,536,315$ & $1,398,244,315$ & $1,518,162,798$ & $1,454,306,421$ & $1,551,019,924$ \\
\hline & & & & & & & & & & & & \\
\hline II & Kapasitas Air Musim Kemaran & \begin{tabular}{|l|}
$307,832,415$ \\
\end{tabular} & $307,832,415$ & $307,832,415$ & \begin{tabular}{|l|}
$307,832,415$ \\
\end{tabular} & $307,832,415$ & $307,832,415$ & \begin{tabular}{|l|}
$307,832,415$ \\
\end{tabular} & $307,832,415$ & $307,832,415$ & $307,832,415$ & $307,832,415$ \\
\hline & & & & & & & & & & & & \\
\hline III & DemandSulpai & 3.49 & 3.62 & 3.76 & 3.91 & 4.05 & 4.21 & 4.37 & 4.54 & 4.71 & 4.88 & 5.04 \\
\hline
\end{tabular}

Tabel 11. Kebutuhan / Volume Sarana Penampung Air ( Reservoar )

\begin{tabular}{|c|c|c|c|c|c|c|c|c|c|c|c|c|}
\hline \multirow{3}{*}{ I. } & \multirow[b]{2}{*}{ Uraian } & \multicolumn{11}{|c|}{$\mathrm{m}$} \\
\hline & & 2002 & 2003 & 2004 & 2005 & 2006 & 2007 & 2008 & 2009 & 2010 & 2011 & 2012 \\
\hline & & & & & & & & & & & & \\
\hline \multicolumn{13}{|c|}{ Kapasitas Air - Kebutuhan Air Bersih dan Industri } \\
\hline & a. Kapasitas air mosim kemaran & $307,832,415$ & $307,832,415$ & $307,832,415$ & $307,832,415$ & $307,832,415$ & $307,832,415$ & $307,832,415$ & $307,832,415$ & $307,832,415$ & $307,832,415$ & $307,832,415$ \\
\hline & b. Kebutuham air bersih & \begin{tabular}{|l|l|l}
$44,017,816$ \\
\end{tabular} & $45,716,620$ & $47,591,529$ & $49,642,852$ & $51,869,901$ & $54,273,323$ & $56,852,996$ & $59,609,057$ & $62,541,367$ & $65,650,157$ & $68,935,406$ \\
\hline & c. Kebuthhan air industri & $4,059,713$ & $4,111,725$ & $4,163,738$ & $4,215,750$ & $4,267,763$ & $4,319,775$ & $4,371,788$ & $4,423,800$ & $4,475,813$ & $4,527,825$ & $4,579,838$ \\
\hline & Vohmme Sisa Air & $259,754,886$ & $258,004,070$ & $256,077,148$ & $253,973,813$ & $251,694,751$ & $249,239,317$ & $246,607,631$ & $243,799,558$ & $240,815,235$ & $237,654,433$ & $234,317,171$ \\
\hline & & & & & & & & & & & & \\
\hline \multicolumn{13}{|c|}{\begin{tabular}{|l} 
Kebutuhan Air Pertanian - Yohme Air Sisa \\
\end{tabular}} \\
\hline & a. Kebutuhan Air Pertanian & $1,025,430,323$ & $1,063,387,200$ & $1,104,839,455$ & $1,149,773,491$ & $1,191,367,845$ & $1,235,903,675$ & $1,283,311,531$ & $1,334,211,458$ & $1,384,128,439$ & $1,433,434,773$ & $1,477,504,680$ \\
\hline & b. Yohme Sisa Air & $259,754,886$ & $258,004,070$ & $256,077,148$ & $253,973,813$ & $251,694,751$ & $249,239,317$ & $246,607,631$ & $243,799,558$ & $240,815,235$ & $237,654,433$ & $234,317,171$ \\
\hline & Yohme Sarana Penampung & $765,675,437$ & $805,383,130$ & $848,762,307$ & $895,799,678$ & $939,673,094$ & $986,664,358$ & $1,036,703,900$ & $1,090,411,900$ & $1,143,313,204$ & $1,195,780,340$ & $1,243,187,509$ \\
\hline
\end{tabular}


Tabel 12. Rencana Strategi Pengembangan

\begin{tabular}{|c|c|c|c|c|c|c|c|c|c|c|c|c|}
\hline \multirow[b]{2}{*}{ No. } & \multirow[b]{2}{*}{ Uraian } & \multicolumn{11}{|c|}{ Tahun } \\
\hline & & 2002 & 2003 & 2004 & 2005 & 2006 & 2007 & 2008 & 2009 & 2010 & 2011 & 2012 \\
\hline & & & & & & & & & & & & \\
\hline 1 & \multicolumn{12}{|c|}{ Prosentase Tingkat Pelayanan (\%) } \\
\hline 1.1 & \multicolumn{12}{|l|}{ Pelayanan Domestik (\%) } \\
\hline & Kejayan & 51 & 53 & 55 & 57 & 59 & 61 & 63 & 65 & 67 & 69 & 71 \\
\hline & Pandaan & 28 & 32 & 36 & 40 & 44 & 48 & 52 & 56 & 60 & 64 & 68 \\
\hline & Gempol & 50 & 52 & 54 & 56 & 58 & 60 & 62 & 64 & 66 & 68 & 70 \\
\hline & Rembang & 11 & 15 & 19 & 23 & 27 & 31 & 35 & 39 & 43 & 47 & 51 \\
\hline & Kraton & 82 & 83 & 84 & 85 & 86 & 87 & 88 & 89 & 90 & 91 & 92 \\
\hline & Lekok & 95 & 95 & 95 & 96 & 97 & 97 & 97 & 97 & 97 & 97 & 97 \\
\hline 1.2 & Pelayanan Industri (\%) & 40 & 20 & 20 & 20 & 20 & 20 & 20 & 20 & 20 & 20 & 20 \\
\hline & & & & & & & & & & & & \\
\hline 2 & Tingkat Kebocoran (\%) & 20 & 20 & 20 & 20 & 20 & 20 & 20 & 20 & 20 & 20 & 20 \\
\hline & & & & & & & & & & & & \\
\hline 3 & Faktor Hari Maksimum & 1.1 & 1.1 & 1.1 & 1.1 & 1.1 & 1.1 & 1.1 & 1.1 & 1.1 & 1.1 & 1.1 \\
\hline
\end{tabular}

Tabel 13. Rencana Kebutuhan Air pada Daerah Pengembangan

\begin{tabular}{|c|c|c|c|c|c|c|c|c|c|c|c|c|}
\hline \multirow[b]{2}{*}{ No. } & \multirow[b]{2}{*}{ Lokasi } & \multicolumn{11}{|c|}{ Tahun } \\
\hline & & 2002 & 2003 & 2004 & 2005 & 2006 & 2007 & 2008 & 2009 & 2010 & 2011 & 2012 \\
\hline & & & & & & & & & & & & \\
\hline 1 & Kejayan & 91 & 96 & 102 & 108 & 114 & 121 & 128 & 136 & 143 & 153 & 161 \\
\hline 2 & Pandaan & 73 & 87 & 101 & 118 & 135 & 154 & 175 & 197 & 222 & 249 & 278 \\
\hline 3 & Gempol & 146 & 160 & 175 & 193 & 212 & 233 & 256 & 281 & 308 & 339 & 370 \\
\hline 4 & Rembang & 28 & 36 & 44 & 54 & 64 & 76 & 89 & 103 & 117 & 137 & 154 \\
\hline 5 & Kraton & 186 & 196 & 206 & 219 & 231 & 245 & 260 & 275 & 291 & 311 & 329 \\
\hline 6 & Lekok & 160 & 170 & 182 & 198 & 215 & 231 & 249 & 268 & 289 & 311 & 335 \\
\hline & & & & & & & & & & & & \\
\hline 'otal & [ liter/detik & 684 & 745 & 810 & 890 & 971 & 1,060 & 1,157 & 1,260 & 1,370 & 1,500 & 1,627 \\
\hline
\end{tabular}

\section{KESIMPULAN DAN REKOMENDASI}

\subsection{Kesimpulan}

Beberapa kesimpulan yang diperoleh dari Pengelolaan Potensi Sumber Daya Air di Kabupaten Pasuruan adalah sebagai berikut :

a. Penentuan kapasitas sumber daya air menggunakan prinsip keseimbangan air (water balance) disesuaikan dengan konsep Pengembangan Sumber Daya Air yang berwawasan lingkungan dan berkesinambungan / berkelanjutan sesuai dengan intisari Rencana Undang - Undang Pengairan.

b. Total Kapasitas sumber daya air di Kabupaten Pasuruan 5.563.823.186 $\mathrm{m}^{3} /$ tahun atau 193.735 liter/ detik dengan perincian $4.933 .876 .748 \mathrm{~m}^{3} /$ tahun atau 174.212 liter/detik air permukaan dan 629.946.438 $\mathrm{m}^{3} /$ tahun atau 19.523 liter/ detik air bawah tanah.

c. Cadangan air bawah tanah Kabupaten Pasuruan 1.828.699.720 $\mathrm{m}^{3}$. d. Proyeksi kebutuhan air di Kabupaten Pasuruan sampai dengan tahun 2012:

- Kebutuhan air Domestik = 137.870.812 $\mathrm{m}^{3} /$ Tahun atau 4.371,85 liter/ detik

- Kebutuhan Air Industri = 9.159.675 $\mathrm{m}^{3}$ / Tahun atau 290,45 liter/ detik

- Kebutuhan Air Pertanian =2.955.009.359 $\mathrm{m}^{3} /$ Tahun atau 93.702,73 liter/ detik

e. Total kebutuhan air di Kabupaten Pasuruan sampai tahun 2012 adalah 3.102.039.846 $\mathrm{m}^{3} /$ Tahun atau 98.365,04 liter/ detik.

f. Kebutuhan reservoar atau Bangunan Penampung Air Hujan dalam upaya memenuhi kebutuhan air di musim kemarau di Kabupaten Pasuruan tahun 2012 adalah sebesar 1.243.187.507 $\mathrm{m}^{3}$.

g. Pemanfaatan air bawah tanah secara resmi (berijin) saat ini sebesar 1.752 liter/detik atau mendekati $10 \%$ dari kapasitas air bawah tanah. Prosentase tersebut dapat lebih besar atau bahkan 
melebihi lapasitas air bawah tanah apabila termasuk pengambilan air yang tidak resmi (tidak berijin)

h. Dalam upaya menjaga kelestarian dan kapasitas sumber daya air di Kabupaten Pasuruan khususnya air bawah tanah perlu ditetapkan zona konservasi air bawah tanah.

i. Pengembalian air bawah tanah harus disesuaikan dengan kapasitas yang ada, jangan sampai melebihi kapsitas tersedia, sehingga akan mengakibatkan berkurangnya cadangan air bawah tanah.

\subsection{Rekomendasi}

Hal - hal yang perlu ditindak lanjuti setelah Studi Pengelolaan Sumber Daya Air di Kabupaten Pasuruan antara Iain :

a. Diperlukan pekerjaan terinci (detail Design) untuk penyediaan Reservoar untuk memenuhi kebutuhan air di musim kemarau. b. Diperlukan pekerjaan terinci (detail Design) untuk penyediaan air bersih di daerah yang berpotensi dilayani sistem penyediaan air bersih di bawah pengelolaan PDAM Kabupaten Pasuruan.

c. Dalam upaya menjaga kelestarian dan kapasitas air bawah tanah perlu ditunjang denagn perangkat hukum Perda Konservasi air bawah tanah.

d. Dalam upaya monitoring dan pengelolaan air bawah tanah perlu ditunjang dengan perangkat hukum berupa Perda Monitoring dan pengelolaan air bawah tanah.

\section{DAFTAR PUSTAKA}

Acuan yang dipakai untuk penulisan artikel ini adalah :

[1] Todd, John Wiley and Sons, 1960, "Ground Water Hydrology"

[2] Chay Asdak, 1995, "Hidrologi dan Pengelolaan Daerah Aliran Sungai", Gajah Mada Univercity Press 